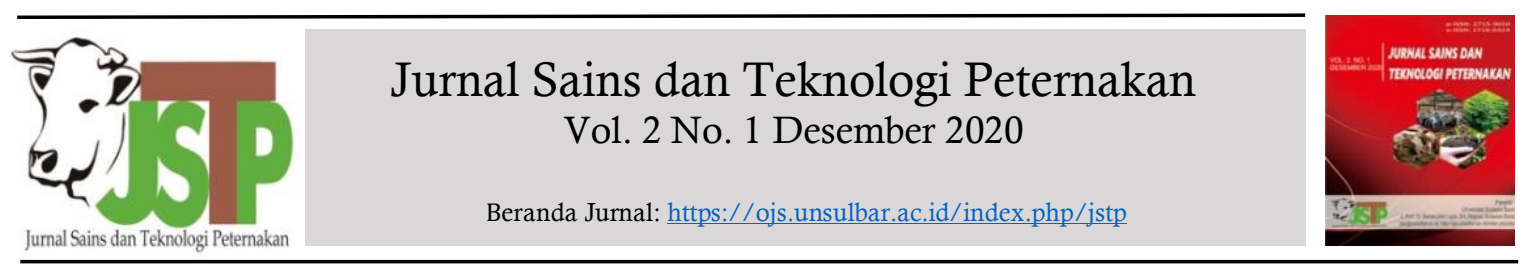

\title{
Tingkat Produktivitas Ternak Usaha Sapi Potong Program Kredit Ternak Sejahtera (KTS) di Kabupaten Berau Kalimantan Timur
}

\author{
(Livestock Productivity Level of Beef Cattle Business in The Prosperous Livestock Credit (PLC) Program \\ on Berau Regency East Kalimantan) \\ Hairudin $^{1^{*}}$, Sri Hartini ${ }^{1}$ \\ ${ }^{1}$ Sekolah Tinggi Ilmu Pertanian Berau, J1. Raja Alam I Teluk Bayur, Kabupaten Berau, Kalimantan Timur
}

A R T I C L I N F O

Received: 10 November 2020

Accepted: 7 Januari 2021

*Corresponding author hairudinmahrup@gmail.com

Keywords:

Beef cattle business Livestock productivity

Prosperous livestock credit (PLC)

Kata Kunci:

Kredit ternak sejahtera (KTS)

Produktivitas ternak

Usaha sapi potong

\section{A B S T R A C T}

This study aims to determine the livestock productivity level of beef cattle business at Prosperous Livestock Credit (PLC) program in Berau regency, East Kaliamntan. This study implemented in Berau regency in three districts namely Teluk Bayur, Sambaliung and Gunung Tabur, with used survey method at PLC program in Berau regency. Data analysis used descriptive analysis by means and standard deviation. The results showed an increase of the beef cattle population in the PLC program by $48.67 \%$ /year from the initial number of beef cattle. Productivity indicated with Pubertas $2.26 \pm 0.40$ years, $S / C 1.35 \pm 0.61$, Pregnancy Rate $283.53 \pm 1.33$ days, Age at First Calving 3.04 \pm 0.40 years, Calving Rate $81 \%$ with female population, Fertility $65 \%$, Mortality $8 \%$ with total population, Oestrus Pospartum 40-60 days, Calving interval 12.4 \pm 0.44 months. The average of beef cattle business in the PLC program was 10.23 AU/farmer.

\section{A B S T R A K}

Penelitian ini bertujuan untuk mengetahui tingkat produktivitas usaha ternak sapi potong program Kredit Ternak Sejahtera (KTS) di Kabupaten Berau, Kalimantan Timur. Penelitian ini dilaksanakan di Kabupaten Berau di tiga kecamatan yaitu: Teluk Bayur, Sambaliung dan Gunung Tabur dengan mengunakan metode survey pada usaha ternak sapi potong program KTS di Kabupaten Berau. Analisis data menggunakan analisis deskritif dalam bentuk rataan dan standard deviasi. Hasil penelitian memperlihatkan peningkatan populasi ternak sapi pada program KTS sebesar 48,67 $\% /$ tahun dari jumlah ternak awal. Produktivitas ternak ditunjukkan dengan Pubertas 2,26 \pm 040 tahun, $S / C 1,35 \pm 0,61$ kali, Pregnancy Rate

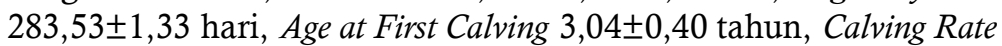
$81 \%$ terhadap populasi betina, Fertility $65 \%$, Mortality $8 \%$ terhadap populasi akhir, Oestrus Pospartum 40-60 hari, Calving interval $12,4 \pm 0,44$ bulan. Pemeliharan ternak sapi potong pada program KTS rata-rata 10,23 ST/peternak. 


\section{Pendahuluan}

Pembangunan pertanian berperan strategis terhadap perekonomian nasional, karena kontribusinya pada berbagai indikator seperti pembentukan kapital, penyediaan bahan pangan, bahan baku industri, pakan dan bioenergi, penyerapan tenaga kerja, sumber devisa negara dan sumber pendapatan. Sebagian besar penduduk Indonesia memiliki mata pencaharian di sektor pertanian sehingga diharapkan dapat memperbaiki pendapatan penduduk secara merata dan berkelanjutan.

Kabupaten Berau merupakan salah satu kabupaten yang berada di Propinsi Kalimantan Timur yang letaknya dibagian utara denga luas wilayahnya $34.127 \mathrm{~km}^{2}$ yang terdiri dari daratan $21.951,71 \mathrm{~km}^{2}$ dan lautan 11.962,42 $\mathrm{km}^{2}$. Kapupaten Berau terbagi atas 13 Kecamatan dengan 97 desa dan 10 kelurahan yang didiami oleh 191.807 jiwa dengan tingkat kepadatan 7,11 jiwa $/ \mathrm{km}^{2}$ (BPS Kabupaten Berau, 2012).

BPS Kalimantan Timur (2012) menginformasikan bahwa populasi sapi sampai akhir tahun 2011 di Kalimantan Timur sebanyak 37,5 persen atau 100.024 ekor dari 7 (tujuh) jenis ternak yaitu sapi potong, sapi perah, kerbau, kambing, domba, babi dan kuda. Sedangkan kegiatan di bidang pertanian yang diusahakan di pedesaan Kabupaten Berau adalah peternakan. Peternakan sebagai penunjang ekonomi yaitu sumber pendapatan dan tabungan sebagian masyarakat Kabupaten Berau. Peternakan yang diusahakan yaitu salah satunya ternak sapi dengan jumlah populasi tahun 2009-2011 berturut-turut 10.263, 10.972 dan 11.524. Jumlah populasi ternak besar dan ruminansia lainnya seperti kerbau, kambing, kuda dan babi populasinya di bawah populasi ternak sapi (BPS Kabupaten Berau, 2012).

Ketersediaan lahan yang luas dan pakan yang berlimpah di Kalimantan Timur termasuk Kabupaten Berau terutama Tanaman Pangan dan Perkebunan yaitu Sisa Hasil Pertanian dan tanaman pakan ternak yang tumbuh disela sela tanaman kelapa sawit sangat menunjang pemenuhan kebutuhan pakan ternak yang dipelihara oleh masyarakat. Sehingga usaha peternakan sapi potong tidak lepas dari usaha pertanian dan perkebunan yang ada dimasyarakat. Sebagaimana disampaikan konsep integrasi ternak dalam usaha tani tanaman baik itu tanaman perkebunan, pangan, atau hortikultura adalah menempatkan dan mengusahakan sejumlah ternak, tanpa mengurangi aktivitas dan produktivitas tanaman. Produktivitas tanaman dapat ditingkatkan dengan adanya ternak ini, sekaligus produksi ternaknya (Daru, Yulianti, \& Widodo, 2014). Hal ini sanagat menunjang kebutahan pakan ternak yang dipelihara oleh peternak dan berpengaruh terhadap produktivitas ternak terutama sifat reproduksi ternak di lapangan yang harus dicatat secara berulang antara lain lama bunting, selang kawin setelah beranak dan selang beranak sehingga capaian Program Kredit Ternak Sejatera (KTS) di Kabupaten Berau terlihat tingkat keberhasilannya dalam meningkatkan populasi ternak dan kesejahteraan masyarakat pada program KTS tersebut.

\section{Metode Penelitian}

Penelitian ini dilaksanakan pada bulan Agustus - Oktober 2013 dengan penentuan responden secara sensus karena pada saat melakukan penelitian peternak yang menerima program KTS yaitu 17 (tujuh belas) peternak sapi potong di Kabupaten Berau yang tersebar di 3 (tiga) kecamatan yaitu Teluk Bayur, Sambaliung dan Gunung Tabur. Penelitian ini menggunakan metode pengumpulan data dengan observasi langsung (direncanakan secara sistematis berkaitan dengan tujuan penelitian, dicatat, serta dapat dicek dan dikontrol atas valiasi dan reabilitasnya), wawancara (belum saling kenal mengenal, pewawancara selalu bertanya, netral, mengikuti panduan dan respoenden selalu menjawab secara langsung dan mengunakan quesioner berupa set pertayaan tentang fakta, pendapat dan presepsi diri (Nasir, 2011). Pengukuran terhadap produktivitas ternak sapi yaitu meliputi: angka kebuntingan (conception rate), jarak antar melahirkan (calving interval), jarak waktu antara melahirkan sampai bunting kembali (service period), angka perkawinan perkebuntingan (service per conception) dan angka kelahiran (calving rate) (Hardjopranjoto, 1995).

Data yang digunakan dalam penelitian ini adalah data primer dan data-data sekunder dari Dinas Pertanian dan Peternakan Kabupaten Berau. Data-data yang diperoleh dengan wawancara dan daftar pertanyaan di analisis dengan analisis deskriptif dalam bentuk rataan dan standard deviasi yang ditabulasi mengunakan microsoft excel.

\section{Hasil dan Pembahasan}

\subsection{Identitas Responden}

Identitas responden usaha ternak sapi potong program KTS di Kabupaten Berau disajikan pada Tabel 1. 
Tabel 1. Kisaran umur responden penerima KTS usaha ternak sapi potong Kabupaten Berau

\begin{tabular}{lcc}
\hline $\begin{array}{l}\text { Kisaran umur } \\
\text { (tahun) }\end{array}$ & $\begin{array}{c}\text { Jumlah responden } \\
\text { (orang) }\end{array}$ & $\begin{array}{c}\text { Persentase } \\
(\%)\end{array}$ \\
\hline $25-35$ & 1 & 5,88 \\
$36-45$ & 3 & 17,65 \\
$46-55$ & 10 & 58,82 \\
$56-65$ & 3 & 17,65 \\
\hline Jumlah & 17 & 100 \\
\hline
\end{tabular}

Sumber: Data responden penerima KTS 2013

Tabel 1 menunjukkan bahwa umur peternak masih berada pada kisaran usia produktif yaitu dibawah 65 tahun, sehingga oleh Bankaltim masih dipercaya memanfaatkan KTS untuk pengembangan usaha ternak sapi potong. Ini disebabkan karena umur sangat erat kaitannya dengan penyediaan tenaga kerja yang produktif sebagaimana disimpulkan Herawati \& Sasana (2013) bahwa umur berpengaruh terhadap produktivitas kerja, dimana semakin bertambah umur maka produktivtas kerja cenderung meningkat.

Tabel 2. Tingkat pendidikan responden penerima KTS usaha ternak sapi potong Kabupaten Berau

\begin{tabular}{lcc}
\hline Pendidikan & $\begin{array}{c}\text { Jumlah } \\
\text { responden } \\
\text { (orang) }\end{array}$ & $\begin{array}{c}\text { Persentase } \\
(\%)\end{array}$ \\
\hline Tidak Tamat SD & 2 & 11,76 \\
Tamat SD & 7 & 411,18 \\
Tamat SMP & 4 & 23,53 \\
Tamat SMA & 4 & 23,53 \\
\hline Jumlah & 17 & 100 \\
\hline Sumber:
\end{tabular}

Sumber: Data responden penerima KTS 2013

Tabel 2 menunjukkan pendidikan sangat bervariasi dari tidak tamat SD sebesar $11,76 \%$, Tamat SD sebesar 41,18\%, Tamat SMP sebesar 23,53 \% dan Tamat SMA sebesar 23,53\%. Pendidikan merupakan bagian penting untuk mendukung usaha yang sedang dijalankan oleh masyarakat sehingga dapat lebih mudah memahami, mengadopsi serta menerapkan teknologi yang sedang berkembang baik dari lingkungannya, pemerintah atau media baik cetak maupun elektronik (Radio atau Televisi).

Tabel 3. Jumlah anggota keluarga responden penerima KTS usaha ternak sapi potong Kabupaten Berau

\begin{tabular}{lcc}
\hline $\begin{array}{l}\text { Jumlah anggota } \\
\text { keluarga }\end{array}$ & $\begin{array}{c}\text { Jumlah responden } \\
\text { (orang) }\end{array}$ & $\begin{array}{c}\text { Persentase } \\
(\%)\end{array}$ \\
\hline $1-2$ & 1 & 5,88 \\
$3-4$ & 6 & 35,29 \\
$5-6$ & 9 & 52,94 \\
$7-8$ & 1 & 5,88 \\
\hline Jumlah & 17 & 100 \\
\hline Sumber: Data responden penerima KTS 2013
\end{tabular}

Tabel 3 memberikan gambaran jumlah anggota keluarga yang dimiliki bervariasi dari beranggota antara 1-2 orang sampai dengan beranggotakan 7-8 orang, tetapi yang terbanyak adalah 5-6 orang yaitu sebesar 52,94\%. Namun keterlibatan anggota keluarga dalam usaha ternak tesebut yang terbanyak 1-2 orang sebesar $64,71 \%$ kemudian $3-4$ orang sebesar $23,53 \%$ dan 5-6 sebesar $11,76 \%$.

Tabel 4. Pengalaman beternak responden penerima KTS usaha ternak sapi potong Kabupaten Berau

\begin{tabular}{lcc}
\hline $\begin{array}{l}\text { Pengalaman } \\
\text { Beternak (tahun) }\end{array}$ & $\begin{array}{c}\text { Jumlah responden } \\
\text { (orang) }\end{array}$ & $\begin{array}{c}\text { Persentase } \\
(\%)\end{array}$ \\
\hline $0-5$ & 4 & 23,53 \\
$60-10$ & 1 & 5,88 \\
$11-15$ & 2 & 11,76 \\
$15-20$ & 4 & 23,53 \\
$>20$ & 6 & 35,29 \\
\hline Jumlah & 17 & 100 \\
\hline
\end{tabular}

Sumber: Data responden penerima KTS 2013

Tabel 4 menunjukkan pengalaman beternak yang dimiliki sebagai berikut: lebih dari 20 tahun sebesar 35,29 \%, 15-20 tahun sebesar 23,53\%, 11-15 tahun sebesar 11,76\%; 6-10 tahun sebesar $5,88 \%$ dan $0-5$ sebesar 23,53\%. Pengalaman beternak merupakan salah satu tolak ukur keberhasilan peternak. Pengalaman akan menunjang peternak dalam mengelola dan menangani ternak yang dipelihara. Semakin lama pengalaman beternak seorang peternak maka akan semakin baik dalam mengelola dan menangani usaha peternakan yang dijalankan.

Tabel 5. Status penguasaan ternak sapi responden penerima KTS usaha ternak sapi potong Kabupaten Berau

\begin{tabular}{lcc}
\hline $\begin{array}{l}\text { Status pengusahaan } \\
\text { ternak sapi }\end{array}$ & $\begin{array}{c}\text { Jumlah } \\
\text { Responden } \\
\text { (orang) }\end{array}$ & $\begin{array}{c}\text { Persentase } \\
(\%)\end{array}$ \\
\hline $\begin{array}{l}\text { Sebagai usaha pokok } \\
\begin{array}{l}\text { Sebagai usaha } \\
\text { sampingan }\end{array}\end{array}$ & 8 & 47,06 \\
\hline Jumlah & 9 & 52,94 \\
\hline Sumber: Data responden penerima KTS 2013 &
\end{tabular}

Tabel 5 menggambarkan bahwa pengusahaan ternak sapi yang dijalankan sebagai usaha pokok dan sampingan masing-masing $47,06 \%$ dan 52,94\%. Hal ini didukung oleh motivasi yang dimiliki peternak antara lain sebagai bisnis, meningkatkan pendapatan, tabungan dan tenaga kerja. Berdasarkan data yang diperoleh adalah 23,53\% sebagai bisnis, $100 \%$ untuk meningkatkan pendapatan, 64,71\% sebagai tabungan dan 52,94\% untuk tenaga kerja.

Semua peternak usaha sapi potong program KTS mengusahakan ternak dengan memilih ternak yang mudah ditangani, mampu beradaptasi dengan kondisi lingkungan, dan 
memelihara bangsa ternak yang mendominasi wilayah tersebut yaitu sapi Bali. Cara pemeliharaan dengan semi intensif yaitu ternak dilepas pada pagi hari di lahan perkebunan coklat yang sudah besar, lahan yang telah ditanami kelapa sawit dan ladang yang digunakan sebagai tempat pengembalaan. Pada malam hari ternak dimasukkan ke dalam kandang dan diberikan makanan berupa rumput yang telah potong dari sawah.

\subsection{Analisa Tingkat Produksi dan Produktivitas Sapi Potong}

Peningkatan populasi ternak pada usaha ternak sapi potong program KTS di Kabupaten Berau karena peternak membeli bakalan ternak yang digemukkan dan dikembangbiakkan serta peternak melakukan usaha pengembangbiakan ternak yang dipelihara sebelumnya atau ternak awal. Peningkatan populasi ternak ini juga kemungkinan dipengaruhi oleh tekanan dari KTS yang diterima, karena peternak akan mengembalikan KTS setiap 6 bulan sekali dengan tepat waktunya yaitu peternak memanfaatkan dana KTS untuk menambah polulasi ternaknya dengan membeli ternak ternak yang produktif (melahirkan 1 kali) dan digunakan sebagiannya untuk usaha penggemukan ternak jantan sehingga sewaktu waktu dapat dijual untuk pengembalian KTS.

Terjadi peningkatan populasi ternak yang sangat signifikan dengan adanya usaha ternak sapi potong program KTS. Peternak pada akhir tahun 2010 (sebelum menerima KTS) memiliki populasi 105 ekor dengan rataan 6,24 $\pm 3,99$ ekor/peternak. Pada saat pengambilan data bulan Agustus - Oktober tahun 2013 populasinya menjadi 261 ekor dengan rataan 15,35 $\pm 9,60$ ekor/peternak. Terjadi peningkatan sebesar 146 $\%$ dari populasi awal selama 3 tahun atau 48,67 $\% /$ tahun. Sebagaimana dinyatakan oleh Wiyatna (2012) bahwa produktivitas ternak sapi dipengaruhi oleh genetik, pakan, dan tatalaksana. Ternak-ternak sapi yang dipelihara pada peternakan rakyat secara umum akan mengalami kekurangan pakan karena jumlah pakan yang diberikan biasanya tidak sesuai dengan kebutuhan ternak, kualitasnya rendah, dan jarang sekali yang memberikan pakan tambahan seperti konsentrat.

Produktivitas ternak sapi potong pada usaha ternak sapi potong program KTS di Kabupaten Berau dari 90 ekor ternak betina pada saat disajikan pada Tabel 6. Produktivitas ternak sapi dipengaruhi oleh tinggi rendahnya efisiensi reproduksi sekelompok ternak ditentukan oleh angka kebuntingan (conception rate), jarak antar melahirkan (calving interval), jarak waktu antara melahirkan sampai bunting kembali (service period), angka perkawinan perkebuntingan (service per conception) dan angka kelahiran (calving rate) (Hardjopranjoto, 1995).

Tabel 6. Tampilan reproduksi ternak sapi potong pada responden penerima KTS usaha ternak sapi potong Kabupaten Berau

\begin{tabular}{lcc}
\hline Variabel & Satuan & Hasil \\
\hline Pubertas & Tahun & $2,26 \pm 0,40$ \\
Service per Conception & Kali & $1,35 \pm 0,61$ \\
Pregnancy Rate & Hari & $283,53 \pm 1,33$ \\
Age at First Calving & Tahun & $3,04 \pm 0,40$ \\
Calving Rate & Persen (\%) & 81 \\
Fertility & Persen (\%) & 65 \\
Mortality & Persen (\%) & 8 \\
Oestrus Pospartum & Hari & $40-60$ \\
Calving interval & Bulan & $12,40 \pm 0,44$ \\
\hline
\end{tabular}

Sumber: Data primer hasil penelitian 2013

Masa Pubertas pada usaha ternak sapi potong program KTS adalah 2,26 $\pm 0,40$ tahun. Hal ini dipengaruhi oleh keadaan lingkungan, pakan dan sistem pemeliharaan yang dilakukan peternak. Kondisi iklim yang dimiliki Kabupaten Berau yang sangat memungkinkan untuk usaha pengembangan ternak sapi potong yang dapat menyiapkan pakan secara terus menerus namun tingkat kualitasnya yang masing rendah dapat mempengaruhi cepat atau lambatnya terjadi pubertas. terlalu luasnya lahan yang dimiliki oleh peternak dimana ternak dilepas pada lahan tersebut menyebabkan energi banyak digunakan untuk bergerak mencari makan (grazing) berdampak terhadap masa pubertas. Menurut Salisbury (1984) masa Pubertas dipengaruhi oleh bangsa, dan tingkat makanan. Hasil ini tidak berbeda dengan apa yang disampaikan Iskandar (2011) masa pubertas pada sapi PO di dataran rendah kecamatan Sekernan yaitu 823,5 hari (2,26 Tahun), namun masih lebih baik pada sapi PO di dataran tinggi kecamatan Kayu Aro yaitu 672.8 hari dan pada sapi bali di Jembrana yaitu $718,57 \pm 12,65$ hari yang dilaporkan oleh Siswanto, Patmawati, Trinayani, Wandia, \& Puja (2013). Pubertas berpengaruh terhadap kawin pertama (First Meeting) pada ternak. First Meeting dipengaruhi oleh manajemen dan perkembangan sapi (Salisbury, 1984).

Service per Conception (S/C) pada usaha ternak sapi potong program KTS adalah $1,35 \pm 0,61$. Hal ini menunjukkan bahwa S/C pada ternak sapi potong di Kabupaten Berau lebih baik dibandingkan sapi Bali di Kepulauan Yapen Papua sebesar 1,49 $\pm 0,09$ (Samberi, Ngadiyono, \& Sumadi, 2010), di dataran rendah di Jambi sebesar 1,5 (Iskandar, 2011), dan 1,52 $\pm 0,19$ (Riyanto, Lutojo, \& Barcelona, 2015), serta dilaporkan oleh Siswanto (2013) yaitu sebesar $1,65 \pm 0,87$ pada sapi Bali dengan 
pemeliharaan instensif di pusat pembibitan sapi Bali Pulukan Jembrana. Lebih lanjut, dilaporkan oleh Nuryadi \& Wahjuningsih (2011) yaitu 1,28 dan Lukman, Busono, Wahyuningsih, \& Suyadi (2014) yaitu 1,23 kali pada sapi Bali di Kabupaten Lombok Barat. Hal ini disebabkan karena faktor yang tidak kalah penting dan berpengaruh terhadap nilai S/C yaitu pengetahuan dan keterampilan peternak dalam mendeteksi birahi (Soeharsono \& Diwyanto, 2010).

Pragnancy Rate adalah periode dari mulai terjadinya fertilisasi sel telur oleh sperma sampai terjadinya kelahiran anak yang berkisar antara 278,8 sampai 291 hari (Prasojo, Arifiantini, \& Mohamad, 2010). Iskandar (2011) menyatakan bahwa Pragnancy Rate dipengaruhi oleh bangsa sapi, jenis kelamin dan jumlah anak yang dikandung, umur induk, musim dan letak geografis. Pragnancy Rate pada usaha ternak sapi potong program KTS adalah sebesar $283,53 \pm 1,33$ hari. Hasil tersebut tidak jauh beda dengan yang dilaporkan oleh (Suranjaya, Ardika, $\&$ Indrawati (2010) yaitu $284,87 \pm 0,33$ hari di wilayah binaan dari proyek Pembibitan dan Pengembangan sapi Bali (P3 Bali) di Bali. Sedangkan. Pragnancy Rate yang terjadi pada ternak sapi yang dipelihara oleh peternak penerima KTS di Kabupaten Berau masih dalam kisaran normal yaitu antara 280-290 hari.

Age at First Calving pada usaha ternak sapi potong program KTS adalah 3,04 $\pm 0,40$ Tahun. Hal ini merupakan dampak dari masa pubertas ternak sapi betina dengan nilai $2,26 \pm 0,40$. Hasil tersebut lebih lama dari yang dilaorkan oleh Samberi et al. (2010) yaitu 2,66 $\pm 0,19$ Tahun (31,92 bulan) pada sapi Bali di Kepulauan Yapen Papua dan $30,17 \pm 4,10$ bulan pada sapi rakyat di kota padang (Reswati, Jaswandi, \& Nurdin, 2014). Sedangkan Age at First Calving pada sapi program KTS lebih pendek dari pusat pembibitan sapi Bali yang memiliki rataan 43,86 bulan (Gunawan, Sari, Parwoto, \& Uddin, 2011), namun tidak berbeda jauh dengan yang dilaporkan Siswanto et al. (2013) yaitu $1104,51 \pm 23,82(3,03 \pm 0,03$ Tahun) pada sapi Bali dengan pemeliharaan instensif di pusat pembibitan sapi Bali Pulukan Jembrana.

Calving Rate (CR) pada usaha ternak sapi potong program KTS adalah sebesar $81 \%$ dari total betina yang bunting. CR pada usaha ternak sapi potong program KTS lebih baik dari $C R$ pada sapi bali di Kepulauan Yapen Papua sebesar 72,27 \% (Samberi et al., 2010). Pada sapi PO di Kabupaten Malang dengan CR sebesar $75,34 \%$ (Nuryadi \& Wahjuningsih, 2011) dan masih jauh lebih rendah dari yang dilaporkan oleh Ihsan \& Wahjuningsih (2011) sebesar 64 -
$65 \%$ pada sapi-sapi persilangan di Bojonegoro. Hal ini kemungkinan disebabkan oleh karena ternak dipelihara secara semi intensif, jika ternak tersebut melahirkan dapat segera ditangani oleh peternak karena ternak tersebut pada malam hari sudah dikandang. Selain itu, ternak yang bunting menjelang kelahiran tidak dikeluarkan dari kelompok sekitar 1-2 minggu sebelum kelahiran, serta sebulan sebelum melahirkan ternak mendapatkan makanan yang berkualitas dari peternak. Susilawati (2011) menyatakan bahwa tingkat kesuburan $80 \%$, pengaruh kombinasinya (kesuburan pejantan, kesuburan betina, teknik inseminasi) menghasilkan angka konsepsi sebesar $64 \%$ dengan optimal mencapai $80 \%$. Begitu pula dilaporkan oleh Ihsan (2010). Terdapat beberapa kemungkinan yang menjadi penyebab rendahnya angka konsepsi ini, yaitu: kualitas semen di tingkat peternak menurun, kondisi resepien yang tidak baik karena faktor genetik, atau faktor fisiologis karena kurang pakan, deteksi berahi yang tidak tepat karena kelalaian peternak atau karena silent heat, serta keterampilan inseminator yang masih perlu ditingkatkan.

Fertilitas pada usaha ternak sapi potong program KTS adalah $65 \%$ terhadap betina dewasa. Hasil penelitian ini lebih baik dari yang dilaporkan oleh Ihsan \& Wahjuningsih (2011) bahwa fertilitas pada sapi PO, persilangan Limousin dan persilangan Simental masih tergolong rendah hingga sedang yaitu di bawah angka normal $60 \%$. Hal ini kemungkinan disebabkan karena sapi dara menunjukkan skor intensitas birahi yang lebih baik dibandingkan dengan sapi induk. Diketahui bahwa setiap paritas memiliki intensitas birahi berdasarkan gejala klinis yang berbeda-beda (Wirdahayati, 2010). Hal ini juga dipengaruhi oleh reproduksi sapi yang tidak efisien dimana disebabkan karena sapi yang dikawinkan dengan cara IB pada estrus kedua atau ketiga bahkan ada yang sudah berkali-kali estrus namun tidak dikawinkan (Yulyanto, Susilawati, \& Ihsan, 2014).

Tingkat mortalitas pada usaha ternak sapi potong program KTS adalah $8 \%$ terhadap populasi akhir ternak. Hal ini tidak berbeda jauh dengan yang dilaporkan oleh Gunawan et al. (2011) sebesar 7,58 \%, sedangkan Samberi et al. (2010) melaporkan bahwa terdapat tingkat mortalitas 1,33\% dari total populasi pada sapi Bali di Kepulauan Yapen Papua. Tingkat mortalitas $8 \%$ menyebabkan peternak mengalami kerugian, ditambah lagi dengan bunga kredit harus dibayar oleh peternak.

Oestrus Pospartum pada usaha ternak sapi potong program KTS berkisar antara 40 - 60 Hari. Jika terjadi birahi setelah melahirkan 
peternak akan segera mengawinkan ternaknya dengan pejantan yang tersedia, karena ketersediaan pejantan di daerah tersebut cukup baik. Oestrus Postpartum lebih lama pada ternak yang kekurangan makanan dan pada sapi menyusui 21-80 hari atau rata-rata 70 hari (Salisbury, 1984). Hasil penelitian ini lebih baik dari laporan oleh Suranjaya et al. (2010) yaitu $125,99 \pm 5,97$ hari di wilayah binaan dari proyek Pembibitan dan Pengembangan sapi Bali (P3 Bali) di Bali.

Calving interval pada usaha ternak sapi potong program KTS adalah selama $12,40 \pm 0,44$ bulan. Data yang diperoleh tersebut tidak jauh berbeda dengan yang dilaporkan oleh Gunawan et al. (2011) bahwa sapi Bali rata-rata memiliki calving interval selama 360,93 hari dan $350,46 \pm 27,98$ hari (Siswanto et al., 2013). Hasil penelitian ini lebih baik dari data yang dilaporkan oleh Samberi et al. (2010) dengan calving interval selama $31,92 \pm 0,19$ bulan pada sapi Bali di Kepulauan Yapen Papua. Begitupula dengan calving interval sapi Bali di Bali yaitu selama 400,88 $\pm 6,24$ hari (Suranjaya et al., 2010) dan $14.55 \pm 0.29$ bulan pada sapi di Mojogedang (Riyanto et al., 2015), serta pada sapi peranakan Limosin (selama 451,3 $\pm 19,61$ hari) dan sapi PO (selama 430 $\pm 43,72$ hari) di kabupaten Trenggalek (Yulyanto et al., 2014).

\section{Kesimpulan}

Terjadi peningkatan populasi ternak sapi potong selama 3 tahun yaitu dari 105 ekor menjadi 261 ekor atau meningkat dengan rataan $48,67 \%$ per tahun. Tingkat produktivitas usaha ternak sapi potong program KTS termasuk baik dilihat dari Pubertas pada umur ternak 2,26 $\pm 0,40$ tahun, Service per Conception (S/C) sebesar 1,35 $\pm 0,61$ kali, Pragnancy Rate selama 283,53 $\pm 1,33$ hari, Age at First Calving pada ternak berumur $3,04 \pm 0,40$ tahun, Calving Rate (CR) sebesar $81 \%$, Fertilitas $65 \%$ terhadap populasi betina, Mortalitas sebesar $8 \%$, Oestrus Pospartum 40-60 hari dan Calving interval selama 12,40 $\pm 0,44$ bulan.

\section{Daftar Pustaka}

BPS Kabupaten Berau. (2012). Kabupaten Berau dalam Angka 2012. Retrieved from https://beraukab.bps.go.id/publication/2 012/08/09/f532befeceebf $7793 \mathrm{~b} 01 \mathrm{~b} 5 \mathrm{~b} 9 / \mathrm{ka}$ bupaten-berau-dalam-angka-2012.html

BPS Kamimantan Timur. (2012). Kalimantan Timur Dalam Angka 2012. Retrieved from https://kaltim.bps.go.id/publication/2012 /08/24/96acca635e428093beb42985/kali mantan-timur-dalam-angka-2012.html

Daru, T. P., Yulianti, A., \& Widodo, E. (2014). Potensi hijauan di perkebunan kelapa sawit sebagai pakan sapi potong di Kabupaten Kutai Kartanegara. Pastura, 3(2), 94-98.

Gunawan, A., Sari, R., Parwoto, Y., \& Uddin, M. J. (2011). Non genetic factors effect on reproductive performance and preweaning mortality from artificially and naturally breed in Bali cattle. Journal of the Indonesian Tropical Animal Agriculture, 36(2), 83-90. https://doi.org/10.14710/jitaa.36.2.83-90

Hardjopranjoto, S. (1995). Ilmu Kemajiran pada Ternak. Surabaya: Fakultas Kedokteran Hewan, Universitas Airlangga.

Herawati, N., \& Sasana, H. (2013). Analisis pengaruh pendidikan, upah pengalaman kerja, jenis kelamin dan umur terhadap produktivitas tenaga kerja industri shutllecock Kota Tegal. Diponegoro Journal of Economics, 2(4), 1-8.

Ihsan, M. N. (2010). Indek fertilitas sapi PO dan persilangannya dengan Limousin. Jurnal Ternak Tropika, 11(2), 82-87.

Ihsan, M. N., \& Wahjuningsih, S. (2011). Penampilan reproduksi sapi potong di Kabupaten Bojonegoro. Jurnal Ternak Tropika, 12(2), 74-77.

Iskandar. (2011). Performan reproduksi sapi PO pada dataran rendah dan dataran tinggi di Provinsi Jambi. Jurnal Ilmiah Ilmu-Ilmu Peternakan, 14(1), 51-61.

Lukman, H. Y., Busono, W., Wahyuningsih, S., \& Suyadi, S. (2014). Sperm motility and viability after $\alpha$-Tocopherol dilution in Tris Aminomethane-Base extender during cold storage in Bali bull. International Journal of Chem Tech Research, 6(14), 5726-5732.

Nasir, M. (2011). Metode Penelitian. Bogor: Ghalia Indonesia.

Nuryadi, \& Wahjuningsih, S. (2011). Penampilan reproduksi sapi peranakan ongole dan peranakan limousin di Kabupaten Malang. Jurnal Ternak Tropika, 12(1), 76-81.

Prasojo, G., Arifiantini, I., \& Mohamad, K. (2010). Korelasi antara lama kebuntingan, bobot lahir dan jenis kelamin pedet hasil inseminasi buatan pada sapi Bali. Jurnal Veteriner, 11(1), 41-45.

Reswati, Jaswandi, \& Nurdin, E. (2014). 
Performa reproduksi sapi perah di Sumatera Barat. Jurnal Peternakan Indonesia, 16(3), 157-165. https://doi.org/ 10.25077/jpi.16.3.157-165.2014

Riyanto, J., Lutojo, \& Barcelona, D. M. (2015). Kinerja reproduksi induk sapi potong pada usaha peternakan rakyat di Kecamatan Mojogedang. Sains Peternakan: Jurnal Penelitian Ilmu Peternakan, 13(2), 73-79.

Salisbury, G. W. (1984). Fisiologi Reproduksi dan Inseminasi Buatan pada Sapi (R. Djanuar, Ed.). San Fransisco and London: W.H. Freeman and Company.

Samberi, K. Y., Ngadiyono, N., \& Sumadi. (2010). Estimasi dinamika populasi dan produktivitas sapi Bali di Kabupaten Kepulauan Yapen, Propinsi Papua. Buletin Peternakan, 34(3), 169-177.

Siswanto, M., Patmawati, N. W., Trinayani, N. N., Wandia, I. N., \& Puja, I. K. (2013). Penampilan reproduksi sapi Bali pada peternakan intensif di instalasi pembibitan Pulukan. Jurnal Ilmu dan Kesehatan Hewan, 1(1), 11-15.

Soeharsono, R. A. S., \& Diwyanto, K. (2010). Kinerja reproduksi sapi potong lokal dan sapi persilangan hasil inseminasi buatan di Daerah Istimewa Yogyakarta. Seminar Nasional Teknologi Peternakan dan Veteriner, 89-99. Yogyakarta.

Suranjaya, I. G., Ardika, I. N., \& Indrawati, R. R. (2010). Faktor-faktor yang mempengaruhi produktivitas sapi Bali di wilayah binaan proyek pembibitan dan pengembangan sapi Bali di Bali. Majalah Ilmiah Peternakan, 13(3), 83-87.

Susilawati, T. (2011). Tingkat keberhasilan inseminasi buatan dengan kualitas dan deposisi semen yang berbeda pada sapi Peranakan Ongole. TERNAK TROPIKA Journal of Tropical Animal Production, 12(2), 15-24.

Wirdahayati, R. B. (2010). Penerapan teknologi dalam upaya meningkatkan produktivitas sapi potong di Nusa Tenggara Timur. Wartazoa, 20(1), 12-20.

Wiyatna, M. F. (2012). Produktivitas sapi Peranakan Ongole pada peternakan rakyat di Kabupaten Sumedang. Jurnal Ilmu Ternak Universitas Padjadjaran, 12(2), 22-25.

Yulyanto, C. A., Susilawati, T., \& Ihsan, M. N. (2014). Penampilan reproduksi sapi
Peranakan Ongole (PO) dan sapi Peranakan Limousin di Kecamatan Sawoo Kabupaten Ponorogo dan Kecamatan Tugu Kabupaten Trenggalek. Jurnal IlmuIlmu Peternakan, 24(2), 49-57. 